\title{
TEMPORAL VARIATIONS IN THE CARBON BUDGET OF FOREST ECOSYSTEMS IN SPAIN
}

\author{
Juan Carlos Rodríguez Murillo \\ Centro de Ciencias Medioambientales, Consejo Superior de Investigaciones Científicas, Calle Serrano 115 duplicado \\ 28006 Madrid, Spain
}

\begin{abstract}
Temperate and boreal forests of the Northern Hemisphere have recently been identified as important carbon sinks. Accurate calculation of forest carbon budget and appraisal of the temporal variations of forest net carbon fluxes are important topics to elucidate the "missing sink" question and to follow up the changing carbon dynamics in forests.

In this article, recent carbon budgets of the forests of a region in northern Spain have been calculated using data from forest inventories and a carbon cycle model for the human perturbations to the forests. Two methods are used, one that requires data from two forest inventories (growing stocks), and another that uses data from only one inventory (forest growth). The methods are complementary and give a picture of the temporal evolution of the forest net carbon flux.

Forests in northern Spain are important carbon sinks, accumulating, on average, 2.91 $\pm 0.47 \mathrm{Tg} \mathrm{C} / \mathrm{yr}\left(1.46 \mathrm{Mg} \mathrm{C} \cdot \mathrm{ha}^{-1} \cdot \mathrm{yr}^{-1}\right.$ ) from $1972 / 1973$ to $1986 / 1988$ (these figures have been derived using data from two forest inventories). The big errors associated with the net fluxes of carbon make it difficult to draw out firm conclusions about the temporal dynamics of carbon budgets, but it can be concluded that the net carbon flux from the forests in the north of Spain has experienced drastic changes through the period 1968/1973 until 1982/1988: the sink strength has diminished in this period from $8.4 \pm 4.4$ to $4.9 \pm$ $3.6 \mathrm{Tg} \mathrm{C} / \mathrm{yr}$ (each figure derived from data from one inventory), as a result of the increase of emissions due to human perturbations of the forests (harvest and forest fires), which have not been compensated by an equivalent forest growth. Northern forests represent the largest proportion of the forest carbon sink in Spain. This is a consequence of the high productivity and areal coverage of the fast-growing tree species that dominate the landscape of the region.

Growing stock (timber volume) in the forests of the region has increased by almost a third in $\approx 15 \mathrm{yr}$. Temporal evolution of tree densities (stem diameter distributions) and timber volumes during those years indicate maturation of the forests on average. The growth in timber volume is shown to be due mainly to the increase of mean tree heights in the same diameter classes and not to a shift in the stem diameter distribution toward bigger diameter classes. Reasons for this growth of timber volume are discussed, and although climatic and $\mathrm{CO}_{2}$ fertilization effects may play a role, it is concluded that increase in the growing stock is also compatible with "normal" stand evolution.
\end{abstract}

Key words: carbon cycle; carbon dioxide; carbon sinks; forest carbon budget; northern Spain.

\section{INTRODUCTION}

In recent years, there has been considerable interest in evaluating the carbon budget of forest ecosystems, due to their important role as carbon sources and sinks (Wisniewski and Sampson 1993, Dixon et al. 1994). Small imbalances in the massive fluxes of carbon between the terrestrial biosphere and the atmosphere may significantly increase the accumulation of $\mathrm{CO}_{2}$ in the atmosphere, which is currently due mainly to the use of fossil fuels. The rise of $\mathrm{CO}_{2}$ atmospheric concentrations has been recognized as a major cause of the increasing radiative forcing and of the foreseen climate change (IPCC 1990).

Manuscript received 29 June 1995; revised 1 March 1996; accepted 2 April 1996; final version received 3 June 1996.
The terrestrial biosphere acted as a small sink during the decade of the $1980 \mathrm{~s}$, accumulating $0.3 \mathrm{Pg} \mathrm{C} / \mathrm{yr}$ (IPCC 1994). This indicates that $\mathrm{CO}_{2}$ emissions calculated from deforestation, mainly in the tropics, were more than compensated by net carbon absorption in the world forests, probably including tropical forests (Grace et al. 1995). Forest regrowth in Northern Hemisphere forests (Europe [Kauppi and Tomppo 1993], USA [Heath and Birdsey 1993], Canada [Kurz and Apps 1993, 1994], and the former Soviet Union [Kolchugina and Vinson 1993]) has been identified as an important component of the so-called missing sink (Dixon et al. 1994, IPCC 1994), but there is a considerable flux of carbon $(\approx 1.4 \mathrm{Pg} \mathrm{C} / \mathrm{yr})$ that is still unaccounted for in the terrestrial carbon budget. It is probable that this carbon is accumulating in the remaining 
undisturbed tropical forests, which were thought to be in steady state with respect to carbon content (Grace et al. 1995), although more observations in different places covering longer periods of time must be necessary to confirm this statement. Even if the "missing sink" question is at last answered with the help of these findings, the reasons for the carbon accumulation are not clear. Three mechanisms have been suggested that could explain it: $\mathrm{CO}_{2}$ fertilization, nitrogen fertilization, and climatic effects (IPCC 1990, Dai and Fung 1993). These three effects may be the cause of some of the observed increase in the growing stock of Northern Hemisphere forests; indeed, faster growth of forest stands has been reported for Europe (Kauppi et al. 1992). In the case of Canada, it has been found (Kurz and Apps 1993) that the increase in forest biomass can be explained by the increase in the average forest age, independent of any increase in growth rates.

Even if these mechanisms can explain the long observed imbalance between carbon sources and sinks, it is still necessary to identify the actual spatial distribution of the missing carbon $(1.4 \mathrm{Pg} / \mathrm{yr})$ in the terrestrial biosphere. Lack of reliable forest inventories in many countries of the world, particularly tropical countries, prevents a knowledge of the carbon budgets in these countries as accurate as those in the developed countries. Even in the developed countries, uncertainties in several critical parameters may be important sources of error for the global carbon budgets.

Besides the present carbon balance of the world forests, another crucial question is their future behavior. Environmental change, especially climate change, could significantly affect high- and middle-latitude forests, whereas tropical forests will be mainly affected by continued clearing for agriculture and unsustainable forestry (Dixon et al. 1994).

Two common methods to evaluate the forest carbon budget are based on forest inventories and land use inventories (Rodríguez Murillo 1994). Forest inventory methods are more realistic, but in absence of such forest inventories, only the last method can be used. An eclectic method based on a carbon model combined with forest inventory data has been proposed and applied to Spanish forests at a national scale (Rodríguez Murillo 1994). The purpose of the present work is to compare this method, which only requires data from one forest inventory, with the usual, more direct calculation of carbon accumulation from two successive forest inventories. The method is applied to the forests of northern Spain, for which data from the first and second national forest inventories (FI1 and FI2) exist. Upon obtaining the net forest carbon flux at the time of both inventories, a picture emerges of the temporal behavior of the carbon budget in forests, and possible reasons for this behavior may be investigated.

Some characteristics of the forests of northern Spain

The region under study is a broad rim in the north of the Iberian Peninsula, from the Portuguese to the
French border, with an area of $52406 \mathrm{~km}^{2}$, limited by the Atlantic Ocean at the west and the Cantabric Sea at the north. Four autonomous regions make up the area: Galicia, Asturias, Cantabria, and Basque Country, from west to east. The area is separated from the rest of the Iberian Peninsula by the Cantabric Mountains in the center and by two other mountain ranges in the east and west. The proximity to the sea and the dominant western and northwestern winds give this region a cold-temperate, maritime climate, $\mathrm{C}_{1}$ in A. Miller's classification of world climates (Miller 1966), which changes to a warm-temperate, mediterranean climate $\left(B_{1}\right)$ with a characteristic summer drought in some southern areas of the region (Gandullo 1985). Mean annual rainfall is $\approx 1300 \mathrm{~mm}$ (varying between 700 and $2500 \mathrm{~mm}$ ) and mean annual temperature is $\approx 12^{\circ} \mathrm{C}$ (Font Tullot 1983). According to the phytoclimatic classification of Walter and Lieth (Walter and Lieth 1967) applied by Allué to peninsular Spain (Allué 1966), the region belongs chiefly to class V(VI) (mesophytic Spain with warm temperate winters), with inland areas being part of class IV(VI) (meso-xerophytic Spain with cool temperate winters). Highlands belong to class VI (mesophytic Spain with cool, temperate winters), with wide areas of class $\mathrm{X}$ climate (high mountain climate). There are small areas of climate class IV(V) (mesoxerophytic Spain with warm temperate winters) in inland Galicia.

The region constitutes the majority of the so-called "wet Spain," which is included in the phytogeographic Eurosiberian region, and is located at the limit with the Mediterranean region. The climax vegetation in the region is a temperate broad-leaved forest, whose dominant species varies with the phytoclimatic zone. Inland Galicia and the south of Basque Country show an important mediterranean influx, with Quercus pyrenaica and Quercus faginea being the dominant climax species. A mixed forest of $Q$. robur and $Q$. petraea is the climax formation in the lowlands with mild winters, changing to a beech (Fagus sylvatica) forest where winters are colder (Peinado Lorca and Rivas-Martínez 1987).

The original climax vegetation has been cleared for farming and grazing since ancient times (Bauer 1991). More recently, many forests were severely degraded to obtain wood for charcoal, used in iron melters and for ship building (Bauer 1991). The introduction of plantations with foreign, fast-growing species (Eucalyptus sp., Pinus radiata, and Pinus pinaster) began about a century ago; establishment of plantations was favored by the high productivity of forests in this region, relative to the rest of the Spanish territory, and also because the steep topography of the region does not favor agriculture. Today, $>50 \%$ of the $20000 \mathrm{~km}^{2}$ of treecovered land supports fast-growing and intensively managed plantations of foreign species: $P$. radiata (Basque Country), P. pinaster (Galicia), and Eucalyptus sp. (mostly E. globulus) (Cantabria, Galicia, and 
Asturias). In Asturias, $P$. pinaster and $P$. radiata are also important.

\section{Methods}

The carbon budget of a forest is the result of all the input and output carbon fluxes in the forest. If there is an extraction of biomass from the forest during the period of the carbon budget calculation, one must also consider the carbon flux to the atmosphere from the oxidation of that harvested biomass.

The carbon fluxes in a forest are the photosynthetic flux (gross primary production) and the respiration flux (autotrophic and heterotrophic respiration, which might include forest fires). The balance between these processes depends on the successional stage of the forest (Waring and Schlesinger 1985). Young forests accumulate carbon in tree tissues and soils, as Net Primary Production (NPP) is larger than heterotrophic respiration, which comes mostly from forest soil decomposers. Mature forests tend toward a state in which NPP and heterotrophic respiration equilibrate, with NPP declining and biomass remaining constant or oscillating around a "limit" (Peet 1981). However, it has been pointed out that this situation occurs with steady climatic and environmental conditions, which may be the exception rather than the rule. After reaching a maximum, a net loss of biomass may occur in some oldgrowth forests (Kurz and Apps 1994).

Processes that affect the forest carbon emissions to the atmosphere are forest fires, forest harvest and clearing, and tree damage and death, as well as the decomposition or burning of forest products (wood, paper, etc.). Losses of forest organic matter through erosion and leaching and river transport will not be considered in this work, due to the scarcity of relevant data on forest soil erosion and oxidation rates of removed organic matter. These processes do not seem to represent significant carbon sources or sinks (Bolin 1986). However, erosion removal and transport of soil organic carbon are increasing (Kern 1994), and more research is needed to elucidate the role of these processes in the changing terrestrial carbon cycle.

One can distinguish between "ordinary" and "extraordinary" forest carbon emissions. Ordinary emissions are those from plant litter and soil organic matter that are produced without direct anthropogenic influence. Extraordinary emissions are those caused by direct human perturbations of the forest. In the region under study, such perturbations are timber harvest and forest fires. It has been found that only $4 \%$ of fires in Spain are caused by lightning, which is, by far, the most frequent natural cause of fires; $37 \%$ of fires are of unknown origin, and the other $59 \%$ could be assigned to human causes (Prieto 1995). It is clear that most $\mathrm{CO}_{2}$ emissions from forest fires can be ascribed to human actions. Extraordinary emissions may be prompt (immediate), as the emissions produced during the burning of the forest, or delayed, as those produced by the decay of wastes resulting from fire and harvest and during the decay and destruction of wood products (fuelwood, paper, and wood). Delayed emissions will persist a long time after the perturbation that caused them, and they make up the bulk of emissions, as most of the affected biomass does not oxidize immediately.

The forest carbon budget may be written as:

$$
\mathrm{NFC}=\mathrm{NPP}-\mathrm{OE}-\mathrm{EE},
$$

where NFC is the annual net forest carbon flux, NPP the forest net primary production, and OE and EE, the annual ordinary and extraordinary, respectively, carbon emissions from the forest. NFC is thus the net ecosystem production minus the extraordinary emissions.

Direct application of Eq. 1 is difficult, however, due mainly to the absence of empirical data on NPP from the forests in the study area, as well as to the accompanying uncertainties in NPP and ordinary and extraordinary emissions. In principle, it is simpler to calculate the carbon budget during a period of time by comparing the amounts of carbon stored in the forest at the beginning and at the end of the period; the difference is the net accumulated flux of carbon during the period. To be complete, the inventory of carbon must include carbon in whole-tree biomasses, plant litter, and soil organic matter, as well as the carbon in forest products (timber, paper, etc.), and the residual material remaining after harvest and fires. The accumulated flux of carbon, AFC, can be written as:

$$
\mathrm{AFC}=B\left(t_{2}\right)+\mathrm{FP}\left(t_{2}\right)-B\left(t_{1}\right)-\mathrm{FP}\left(t_{1}\right),
$$

where $B\left(t_{1}\right)$ and $B\left(t_{2}\right)$ are the forest biomasses (expressed as mass of carbon) at the times of the successive forest inventories, including plant litter and soil carbon, and $\operatorname{FP}\left(t_{1}\right)$ and $\operatorname{FP}\left(t_{2}\right)$ are the amounts of carbon in the forest products. The accumulated flux of carbon must be equal to the sum of the annual net forest carbon fluxes between $t_{1}$ and $t_{2}$.

It is possible to derive $B\left(t_{\mathrm{i}}\right)$ from the results of forest inventories with the use of appropriate "expansion factors," $T / M$, which relate the merchantable biomass, $M$, and the total forest biomass, $T$ (Johnson and Sharpe 1983). It has been pointed out (Rodríguez Murillo 1994) that such factors, as well as the estimation of the amount of soil carbon, introduce the main uncertainties in the calculation of forest carbon mass; important additional errors can occur if changes on $B\left(t_{\mathrm{i}}\right)$ and $\operatorname{FP}\left(t_{\mathrm{i}}\right)$ over the period between inventories are small compared to the quantities of carbon stored in biomasses, forest soil, litter, and forest products. A mean annual accumulated flux of carbon for the period between inventories can be obtained by dividing AFC by the number of years passed from the first until the second inventory, but this mean AFC may differ considerably from the net flux of carbon obtained from one inventory (NFC), because this last quantity will reflect recent short-term accumulation or loss of carbon. Short-term (e.g., annual) gains or losses of carbon dur- 
ing several years within a given interval of time may be very different from the average gains or losses along the whole interval, because tree growth varies with time, being very sensitive to short-term temperature and precipitation conditions (Spiecker 1995). Uncertainties in NFC and in the estimation of soil carbon accumulation in the period between inventories may also contribute to the differences between net and accumulated fluxes of carbon, as will be shown.

In the present work, both net and accumulated fluxes of carbon in the forests of the four communities in the region described have been calculated. Net flux of carbon has been calculated using the procedure described in detail elsewhere (Rodríguez Murillo 1994), by means of the relationship:

$$
\mathrm{NFC}=\mathrm{LBI}+\mathrm{LA}-\mathrm{OSE}-\mathrm{EE},
$$

where LBI ("live biomass increment") represents the annual growth of woody biomass in trees, LA is the accumulation of "natural" plant litter in a year (i.e., that not produced as the result of timber harvest or forest fires), OSE is the ordinary soil emissions (i.e., those produced without direct human influence), and $\mathrm{EE}$ is the extraordinary emissions defined above. Some important changes have been introduced in the calculation of the variables in Eq. 3, and will be discussed below. The basic data required from the forest inventory are the annual increase of timber volume, which is obtained from the measurement of the diametric growth in the $5 \mathrm{yr}$ before the inventory, and the timber volume, in conifer and broad-leaved species (ICONA 1979, 1980, 1991, IFCAV 1988). Carbon in wood is obtained assuming mean wood densities for coniferous and broad-leaved trees and using a fraction of carbon in wood of $0.45 \mathrm{~g} \mathrm{C} / \mathrm{g}$ dry matter (Rodríguez Murillo 1994).

Live biomass increment can be estimated from the annual increase in timber volume, expressed in terms of carbon mass, by multiplication with a factor " $c$.", In a previous work (Rodríguez Murillo 1994) this factor was taken as 2.4, without allowing for a range of possible values. In a literature review, looking for data on productivities of representative Spanish and European forest ecosystems, values of $c$ between 1.32 and 2.88 have been found (Reichle 1981, López Arias 1991, Montero et al. 1991), which is in agreement with the data of Whittaker and co-workers (Whittaker and Marks 1975). A range of values for the $c$ factor has thus been taken, from 2.88 (maximum) to 1.32 (minimum), with a mean value of 2.10

The most demanding calculation is that of extraordinary emissions in forests, and it has been made for northern Spain using the carbon model and methodology in Rodríguez Murillo (1994). Six carbon reservoirs, either created or affected by human-caused forest disturbance, are accounted for: logging and fire waste, paper, timber, fuelwood, and charcoal produced by fire and humus. The model calculates the annual carbon
TABLE 1. Parameters and partial values for the calculation of the accumulated fluxes of carbon (AFC) in forests in northern Spain.

\begin{tabular}{ccccccc}
\hline \hline & & & FLB & FLB & $B\left(t_{2}\right)-$ & $\mathrm{FP}\left(t_{2}\right)-$ \\
$(\mathrm{FI})$ & $B\left(t_{1}\right)$ & $\mathrm{FP}\left(t_{1}\right)$ \\
\hline 2.88 & 1.40 & 0.10 & 53.3 & 70.6 & 21.9 & 13.4 \\
2.10 & 1.70 & 0.25 & 64.7 & 85.7 & 30.2 & 12.9 \\
1.32 & 2.00 & 0.40 & 76.1 & 101 & 38.6 & 10.1
\end{tabular}

Note: Wood carbon densities are $0.227 \mathrm{Mg} \mathrm{C} / \mathrm{m}^{-3}$ for conifers and $0.316 \mathrm{Mg} \mathrm{C} / \mathrm{m}^{-3}$ for broad-leaved trees (Rodríguez Murillo 1994). Units of $f$ are $\mathrm{Mg} \mathrm{C} \cdot \mathrm{ha}^{-1} \cdot \mathrm{yr}^{-1}, c$ and $k$ are nondimensional, and the other variables are given as $\mathrm{Tg} \mathrm{C}$. Definitions: $c$ is the ratio of live biomass increment to the annual increase in timber volume, $k$ is an expansion factor relating the forest live biomass and timber volume, $f$ is the forest soil carbon annual accumulation, FLB is the forest live biomass, estimated in the years of the first and second forest inventories (FI1 and FI2, respectively), $B$ is the total forest biomass, including soil organic carbon, and FP is the mass of forest products, both variables estimated in the years $t_{2}$ (second forest inventory) and $t_{1}$ (first forest inventory).

input and output for each reservoir; extraordinary emissions are the sum of the carbon fluxes from these reservoirs to the atmosphere plus $\mathrm{CO}_{2}$ emissions from perturbed forest soils, which are calculated separately.

Data of timber, fuelwood, and pulp production (DGM-EFE 1960-1963, MAPA 1973-1990) and forest fires (DGM 1960-1969, ICONA 1970-1990) are needed. Lack of relevant data on pulp productions and fireaffected volumes of wood made necessary some assumptions and simplifications to apply the model used for the whole of Spain to the north of Spain. The error involved in these simplifications has been estimated applying the simplified model to the whole of Spain and comparing the results with those from the complete model; the simplified model gives somewhat lower annual extraordinary carbon emissions, but the difference with the complete model is generally lower than $10 \%$, which is acceptable, given the much wider uncertainties existing in the calculation of extraordinary emissions (see Results).

Accumulated fluxes of carbon in the four communities in northern Spain have been calculated with Eq. 2. Total forest biomasses, $B\left(t_{\mathrm{i}}\right)$, are the sum of forest live biomass, forest litter, and forest soil carbon. Forest live biomass (FLB) is calculated from timber volumes, obtained in forest inventories, by the expression:

$$
\mathrm{FLB}=k(\text { carbon in timber volume }),
$$

where carbon in timber volume is derived by multiplying the timber volume by the suitable "wood carbon density" (Table 1), and $k$ is an expansion factor relating the forest live biomass and timber volume; $k$ varies with age tree, species, and other stand characteristics (Johnson and Sharpe 1983). A literature search was made afterwards in order to find more precise expansion factors than the range 1.75-3.65 assigned previously to $T / M$ (Rodríguez Murillo 1994); $k$ factors from 1.17 to 2.02 have been found in Spain and Europe 
(Reichle 1981, López Arias 1991, Montero et al. 1991). Finally, three values of $k$ were considered, in order to define a range in which the likely value of the expansion factor is included (Table 1; Rodríguez Murillo 1994); these values were chosen from a more complete set of data (Turner et al. 1995). Forest litter (FL) is estimated as $10 \%$ of FLB (Schlesinger 1977, Rodríguez Murillo 1994). Forest soil carbon (FSC) is calculated by the equation:

$$
\mathrm{FSC}=f \times \mathrm{FLB},
$$

where $f(=2.69)$ is a factor that is estimated as the average from global carbon data on soils and biomasses of the "temperate forests" (Schlesinger 1977) and "warm temperate dry forests" (Post et al. 1982) ecosystem types, to which Spanish forests belong. Work is being performed to assess more precisely the quantity of forest soil carbon in Spain from soil profile carbon data corresponding to Spanish soils.

Whereas $f$ may suffice for a rough estimation of forest soil carbon at the time of a forest inventory, the estimation of soil carbon accumulation between two inventories, calculated as the difference of forest soil carbon in both inventories, obtained with Eq. 5, leads to rates of soil carbon accumulation higher than any found by other workers. Besides, from an ecological point of view, $f$ must change with time, as the rates of accumulation of live biomass and soil carbon vary in time with different patterns.

Taking this into account, forest soil carbon was calculated from Eq. 5 for the first forest inventory. For the second forest inventory, forest soil carbon was estimated as the forest soil carbon corresponding to the first inventory plus a carbon accumulation of $0.25 \mathrm{Mg}$ $\mathrm{C} \cdot \mathrm{ha}^{-1} \cdot \mathrm{yr}^{-1}$; as before with $k$ and $c$, three values of $f$ were used in the calculations (Table 1).

The amount of carbon in forest products (FP) (including here wood, paper pulp, fuelwood, timber residuals from harvest and fires, charcoal, and humus) was estimated using the simplified model for extraordinary carbon fluxes cited previously (Rodríguez Murillo 1994).

\section{Results}

The carbon reservoir and the carbon budget were calculated for the forests of the four autonomous regions in northern Spain for the two forest inventories that exist presently (Tables 1 and 2); field measurements were performed in 1972 and 1973 for the first inventory and in 1986-1988 for the second inventory. NFC are the averages for the $5 \mathrm{yr}$ prior to the forest inventory dates; the corresponding period is written between brackets in Table 2. AFC are obtained by dividing the total carbon accumulation by the number of years passed between the two forest inventories.

Additionally, the carbon budget for the whole of the forests of Spain was recalculated introducing the modifications explained in this work; this carbon budget
TABLE 2. Carbon budgets in forests in north Spain, years 1968-1973, 1982-1988 (NFCs) and 1972-1988 (AFC), in teragrams of carbon by years.

\begin{tabular}{lccc}
\hline \hline \multicolumn{1}{c}{ Region } & NFC (FI1) & NFC (FI2) & AFC \\
\hline Galicia & $4.7 \pm 2.4$ & $3.4 \pm 2.1$ & $1.44 \pm 0.26$ \\
& $(1969-1973)$ & $(1983-1987)$ & $(1973-1987)$ \\
Basque Country & $2.1 \pm 1.0$ & $0.33 \pm 0.48$ & $0.73 \pm 0.11$ \\
& $(1968-1972)$ & $(1982-1986)$ & $(1972-1986)$ \\
Asturias & $1.2 \pm 0.7$ & $0.80 \pm 0.63$ & $0.41 \pm 0.06$ \\
& $(1969-1973)$ & $(1984-1988)$ & $(1973-1988)$ \\
Cantabria & $0.40 \pm 0.32$ & $0.41 \pm 0.38$ & $0.33 \pm 0.04$ \\
& $(1968-1972)$ & $(1984-1988)$ & $(1972-1988)$ \\
Total & $8.4 \pm 4.4$ & $4.9 \pm 3.6$ & $2.91 \pm 0.47$ \\
\hline
\end{tabular}

Note: NFC is the annual net forest carbon flux during the $5 \mathrm{yr}$ (in parentheses) previous to the first and second forest inventories (FI1 and FI2), and AFC is the average flux of carbon during the years in parentheses.

was evaluated, in a previous article, for the years 19661974 (Rodríguez Murillo 1994). The Spanish forests accumulated throughout that period between 6.0 and $17 \mathrm{Tg} \mathrm{C} / \mathrm{yr}$ (11 Tg C/yr as an average value).

Accuracy of calculation of NFC using Eq. 3 depends on the accuracy of basic data of annual increment of timber volume. After publication of the carbon budget of the Spanish forests (Rodríguez Murillo 1994), which include the forests in the area under study, suspicions arose that forest growth had been overestimated in the first forest inventory in some autonomous regions (José A. Villanueva, personal communication), due to the use of incorrect growth equations. This seems to be the case in Galicia, where growth of Eucalyptus sp. and $P$. pinaster was clearly overestimated. NFC calculated for the years of the first forest inventory is then too big, by an unspecified amount, and should be taken with caution.

The forests in northern Spain have been accumulating carbon from 1972/1973 until 1986/1988. Applying Eq. 2 to the data in Table 1, a medium accumulation of $43.1 \mathrm{Tg} \mathrm{C}$ (maximum $=48.7$, minimum $=35.3 \mathrm{Tg}$ C) is deduced. About a half of the accumulation took place as forest live biomass, and almost $30 \%$ of the total carbon sequestration occurred in forest products. Mean annual carbon absorption (i.e., the annual average accumulated flux of carbon) was $2.91 \pm 0.47 \mathrm{Tg}$ $\mathrm{C} / \mathrm{yr}$ during this period, being higher immediately before the period (net flux of carbon from the first forest inventory $=8.4 \pm 4.4 \mathrm{Tg} \mathrm{C} / \mathrm{yr}$ ) and at the end of the period studied (net flux of carbon from the second forest inventory $=4.9 \pm 3.6 \mathrm{Tg} \mathrm{C} / \mathrm{yr}$ ) (Table 2). This same pattern of variation occurs in Galicia and Asturias, whereas the Basque Country shows an AFC value intermediate between the net fluxes of carbon from both inventories, and Cantabria presents an almost constant rate of carbon accumulation.

Carbon densities are much higher in this region than in the Spanish forest, on average, due to the different climatic environments and, particularly, to the prevalence of high-yield tree plantations in northern Spain. 
A standard error calculation is not possible, as errors in the parameters used in the calculations are not known. Varying the factors $c, f$, and $k$ as in Table 1 , one obtains a range of three NFC and AFC values, the difference between the two extreme values serving as a measure of the uncertainty range of the variable. In the case of NFC, the "extraordinary emissions" term was computed with the "high emissions," "medium emissions," and "low emissions" hypotheses, which take into account the uncertainty of other parameters in the carbon cycle model (Rodríguez Murillo 1994).

Besides the uncertainties in the three factors just mentioned, one can think of other error sources, such as consistency of measurements and basic data treatment in both forest inventories, and the assumption of a range of values for the factors and parameters used that does not change in time or space. It is clear that these factors vary, as was pointed out in the case of $k$ and $f$, and a more accurate calculation of the carbon budgets should include a stratification of the forests according to the different values of the factors in the different forest types. Unfortunately, lack of data has necessitated treating the diverse forests in the area under study as a single forest. The error associated with this "lumping," however, should already be included into the previous error intervals, as a range of values for the factors $c, k$, and $f$ was chosen.

Consistency of measurements and data processing in successive forest inventories is necessary to obtain meaningful data for carbon accumulation or loss through the accumulated flux of carbon. To calculate AFC, only inventory data on timber volumes and forested surfaces are needed, and these are more reliable than the increment of timber volume data. Statistical errors in timber volumes are small compared with increase in timber volumes obtained through difference of timber volumes in the forest inventories (Table 3C), but may be of the same magnitude as the errors that affect AFC (Table 2). The total error in each AFC must therefore be greater than the error in Table 2. No attempt was made to quantify the effects of statistical errors in timber volumes on the accumulated fluxes of carbon.

\section{DISCUSSION}

Carbon accumulation in northern Spain was remarkable in the period studied (Tables 1 and 2). In the whole of Spain, carbon accumulation during the years 19661974 was $11 \mathrm{Tg} \mathrm{C} / \mathrm{yr}\left(0.93 \mathrm{Mg} \mathrm{C} \cdot \mathrm{ha}^{-1} \cdot \mathrm{yr}^{-1}\right)$, which is a high value in comparison to the European average (0.4-0.6 Mg C. $\mathrm{ha}^{-1} \cdot \mathrm{yr}^{-1}$ ) (Kauppi et al. 1992), similar to that estimated for Holland (0.97 Mg C.ha- $\mathrm{ha}^{-1} \cdot \mathrm{yr}^{-1}$ ) (Nabuurs and Mohren 1995), and lower than that of the USA (1.2 $\left.\mathrm{Mg} \mathrm{C} \cdot \mathrm{ha}^{-1} \cdot \mathrm{yr}^{-1}\right)$ (Heath and Birdsey 1993). With only $17 \%$ of total forest surface, forests in the north of Spain accumulated the majority $(8.4 \mathrm{Tg}$ $\mathrm{C} / \mathrm{yr}$ ) of the carbon absorbed by the whole Spanish forests during the years of the first forest inventory
TABLE 3. Forest areas in the forest inventories $\left(10^{3} \mathrm{ha}\right)$ (ICONA 1979, 1980, 1991, IFCAV 1988).

\begin{tabular}{|c|c|c|c|c|c|}
\hline $\begin{array}{l}\text { Autonomous } \\
\text { region }\end{array}$ & Galicia & Asturias & Cantabria & $\begin{array}{l}\text { Basque } \\
\text { Country }\end{array}$ & Total \\
\hline FI1 & 1129 & 363.3 & 173.4 & 353.5 & 2020 \\
\hline FI2 & 1045 & 368.1 & 165.5 & 384.8 & 1964 \\
\hline Diff. (\%) & -7.4 & +1.3 & -4.6 & +8.8 & -2.8 \\
\hline
\end{tabular}

B) Number of trees $\left(10^{6}\right.$ individuals in $10-\mathrm{cm}$ and larger diameter classes) (ICONA 1979, 1980, 1991, IFCAV 1988).

$\begin{array}{lllllc}\text { FI1 } & 628.1 & 219.1 & 92.34 & 239.4 & 1179 \\ \text { FI2 } & 419.1 & 176.0 & 97.31 & 175.5 & 868.7 \\ \text { Diff. (\%) } & -33.1 & -19.7 & +5.4 & -26.7 & -26.3\end{array}$

C) Timber volumes including bark $\left(10^{6}\right.$ tons of carbon $)$ $($ ICONA 1979, 1980, 1991, IFCAV 1988). FI1 = first forest inventory; FI2 = second forest inventory.

$\begin{array}{lrrrrr}\text { FI1 } & 18.3 & 8.14 & 4.16 & 7.48 & 38.1 \\ \text { FI2 } & 23.9 & 9.65 & 5.88 & 11.0 & 50.4 \\ \text { Diff. }(\%) & +30.7 & +18.6 & +41.1 & +46.8 & +32.4\end{array}$

D) Annual increments of timber volumes $\left(10^{6} \mathrm{~m}^{3}\right)$ (ICONA 1979, 1980, 1991, IFCAV 1988)

\begin{tabular}{lcrrrr} 
FI1 & 10.0 & 2.57 & 1.02 & 4.65 & 18.2 \\
FI2 & 8.18 & 2.14 & 1.19 & 1.71 & 13.2 \\
Diff. (\%) & -18.2 & -16.7 & +15.9 & -63.2 & -27.5 \\
\hline
\end{tabular}

(1968-1973), even allowing for an overestimation of the last figure. Even considering that a small underestimation of the annual increase in timber volume in the part of Spain outside the region under study may exist, due to the fact that increases in timber volumes of Quercus ilex and Quercus suber are not measured in the forest inventories (even though the first is the most characteristic species in mediterranean Spain), it is clear that forest growth and carbon accumulation took place predominantly in northern Spain during the first forest inventory. The mediterranean area of Spain, which makes up most of peninsular Spain, showed a minor role as a carbon sink. No corresponding data for the second forest inventory are yet available, as this inventory has not been finished for the whole of Spain.

The big errors associated with the net fluxes of carbon make it difficult to draw firm conclusions about the temporal dynamics of carbon budgets, but some facts can be asserted. First, the net carbon flux from forests in northern Spain has undergone radical changes through the period 1968/1973 (first forest inventory) until 1982/1988 (second forest inventory) (Table 2). Also, a trend of decreasing carbon absorption can be deduced comparing the carbon accumulations during the two forest inventories (NFCs), which is the result of the growth of extraordinary emissions in northern Spain, as a consequence of intensified human exploitation of the region forests. Logging more than doubled in the period between the first and second forest inventories, and represented $\approx 40 \%$ of the measured forest growth in the years of the second forest inventory. The weakening of the carbon sink might also be a consequence of the decrease of the annual increment of timber volume (Table 3D), but data for the first forest 


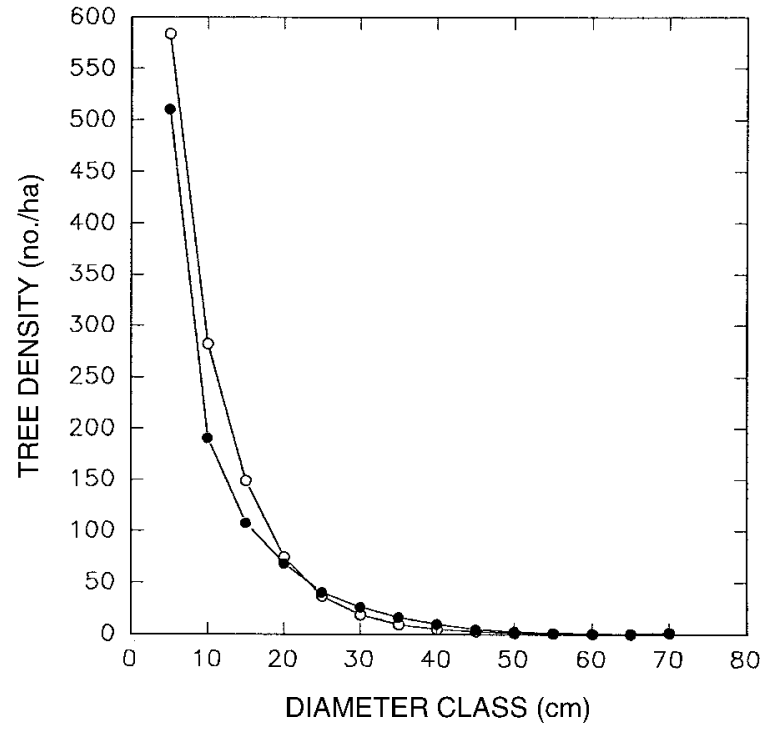

FIG. 1. Tree density distributions by diameter class (stem diameter distributions) in forests of northern Spain. $\bigcirc$ : first forest inventory (1972/1973) (ICONA 1979, 1980); 0: second forest inventory (1986/1988) (IFCAV 1988, ICONA 1991).

inventory are overestimated, as has been pointed out, and should therefore be taken with caution.

The average carbon flux through the years between forest inventories is estimated as $2.91 \pm 0.47 \mathrm{Tg} \mathrm{C} / \mathrm{yr}$ $\left(1.46 \mathrm{Mg} \mathrm{C} \cdot \mathrm{ha}^{-1} \cdot \mathrm{yr}^{-1}\right)$. Due to the difference in the methods of calculation of NFC and AFC, comparison between these fluxes is less meaningful than the comparison between net fluxes of carbon, but, nevertheless, a drop in the strength of the carbon sink is apparent in the period. An increase of carbon absorption in 19821988 (second forest inventory) relative to the accumulated flux may be an artifact, considering the big errors in NFC, but might also be due to a short-term stimulation of growth due to favorable climatic conditions. As was pointed out, net fluxes of carbon, which are short-term gains or losses of carbon during several years within a given interval of time, may be very different from the accumulated fluxes of carbon, which represent average gains or losses during the whole interval.

Changes in some forest characteristics from the first to the second forest inventory are presented in Table 3. Forests in northern Spain represented 30.6\% of timber volume and $58.1 \%$ of forest growth (annual increase in timber volume) in Spain in the years of the first forest inventory (Rodríguez Murillo 1994), with only $17 \%$ of the total tree-covered area.

Stem diameter distributions for all the tree species in the forest inventories are represented in Fig. 1. These are decreasing, J-shaped curves, typical from large regions (Loetsch et al. 1973). There has been a decline in the number of trees in the region, whose forested area has remained almost the same. This decline is not uniform through the different diameter classes, and is most noticeable in the small diameters, especially in DC (diameter classes) 10 and 15, indicating a deficit of young individuals, while the number of more mature trees $(\mathrm{DC}>20)$ increases. A shift is apparent in the tree distribution toward more mature forests. A similar phenomenon has been found for the Canadian forests (Kurz and Apps 1993). At the same time, timber volume has increased by almost a third (Table 3C, Fig. 2).

It is well known that forest maturation is accompanied, at the stand level, by a decreasing number of individuals and an increase of biomass and, particularly, of timber volume (Waring and Schlesinger 1985). Both principles seem to apply as well to all the forests of northern Spain, indicating that young successional forests and tree plantations dominate the dynamics of these forests.

It is difficult to give one unambiguous interpretation of the evolution of the timber in the period between forest inventories, but one can conclude that the forests in northern Spain are in a period of biomass accretion, as has been reported for northern Europe (Kauppi et al. 1992). But, in contrast with Europe, forest growth in the forests of northern Spain does not seem to have increased in the last $15 \mathrm{yr}$, unless the annual increase in timber volume was grossly overestimated in the first forest inventory.

Growth of timber volume is not merely an artifact caused by the shift of stem diameter distributions toward bigger diameters, i.e., toward more mature for-

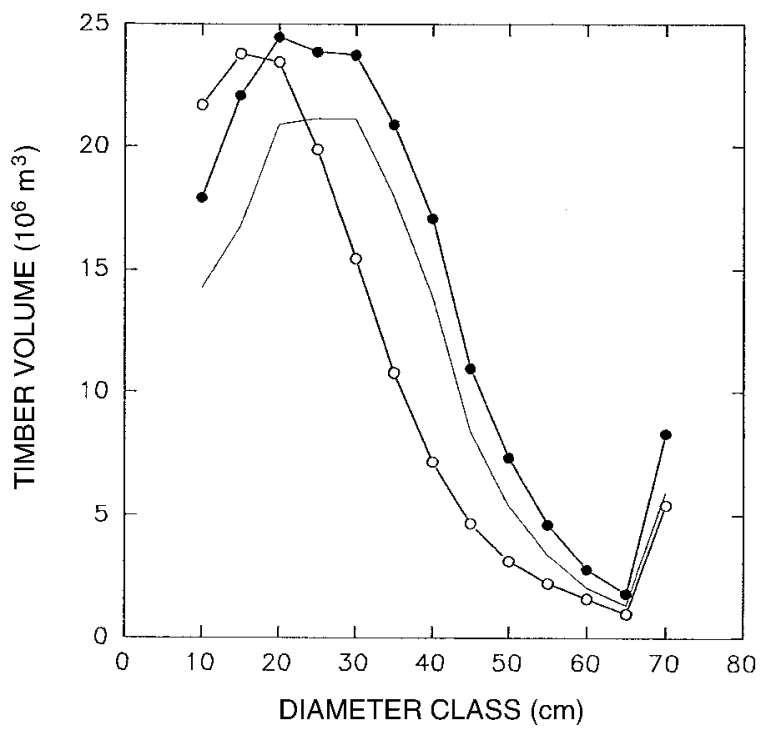

FIG. 2. Timber volume distributions by diameter class. $\bigcirc$ : first forest inventory (1972/1973) (ICONA 1979, 1980); - second forest inventory (1986/1988) (IFCAV 1988, ICONA 1991). Line without symbols represents the calculated timber volumes for the second forest inventory, assuming that only the tree diameter distribution has changed from the first to the second forest inventory. 


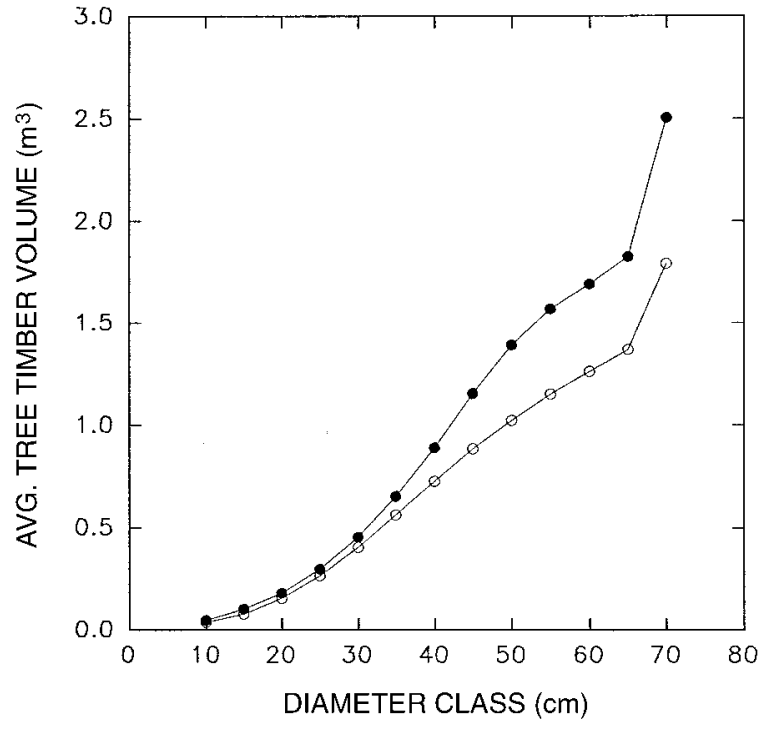

FIG. 3. Distribution of average tree timber volumes in the two forest inventories. $\bigcirc$ : first forest inventory (1972/1973) (ICONA 1979, 1980); : second forest inventory (1986/ 1988) (IFCAV 1988, ICONA 1991).

ests. This can be demonstrated by calculating the timber volume in FI2, assuming that only the tree diameter distribution changed from FI1 to FI2. To do that, it is assumed that average tree timber volume remains the same for every diameter class in FI2, and the actual tree distribution from FI2 is multiplied by the average tree timber volume derived from FI1. Total timber volumes are 140.2 (FI1), 185.9 (actual timber volume in FI2), and 152.7 (calculated timber volume in FI2) $\times$ $10^{6} \mathrm{~m}^{3}$ (Fig. 2). The bulk of the increase in the timber volume should then be ascribed to the increase in the average tree timber volume, which is bigger in the second forest inventory than in the first forest inventory for every diameter class (Fig. 3); mean tree height increased in almost all the diameter classes of the main tree species, as one can see in the forest inventories. A similar observation was made (Siccama et al. 1994) in the Hubbard Brook forest.

The increase of average tree timber volume in every diameter class from FI1 to FI2 might be due to several causes: change in species composition (more proportion of fast-growing species in the second forest inventory), stand evolution, including silviculture (Loetsch et al. 1973), or increase in growth rates due to climatic effects (Dai and Fung 1993, Spiecker 1995), and/or fertilization by nitrogen or $\mathrm{CO}_{2}$. In order to detect an acceleration in growth rates a baseline is needed. For example, one might compare timber volumes of an age class at two points in time; an increase in growth rates would imply that a larger timber volume should be found in that age class at the later time. Unfortunately, comparison between timber volumes in a diameter class cannot directly provide such information, as diameter class is not unequivocally related to tree age: the same diameter classes in (even aged) stands of different ages show different heights ("normal", stand development), with the height (and thus also the timber volume) of a given diameter class increasing with stand age (Loetsch et al. 1973). As shown above, fast-growing even-aged stands of increasing age dominate the forest dynamics in northern Spain, so one can qualitatively attribute the increase in average tree timber volume to the normal development of fast-growing stands in the period studied. Identification and quantification of possible climatic and fertilization effects would require long-term observations of growth trends (Spiecker 1995) and, although such effects may contribute to the observed carbon sink, their participation could not be separated from the "normal" stand development factor.

\section{ACKNOWLEDGMENTS}

I wish to thank Dr José A. Villanueva Aranguren and people from ICONA (Institute for Nature Conservation) for their help with forest inventories and forest fire data, and Dr. M. J. Apps for his critical review of the original manuscript. This work is part of a contract with the Dirección General de Política Ambiental del Ministerio de Obras Públicas, Transportes y Medio Ambiente for the study of carbon interchange between the atmosphere and the terrestrial ecosystems within the Spanish territory.

\section{Literature Cited}

Allué, J. L. 1966. Subregiones fitoclimáticas de España. Instituto Forestal de Investigaciones y Experiencias, Madrid, Spain.

Bolin, B. 1986. How much $\mathrm{CO}_{2}$ will remain in the atmosphere? Pages 142-143 In B. Bolin, B. R. Döös, J. Jäger, and R. A. Warrick, editors. The greenhouse effect, climate change and ecosystems. Wiley \& Sons, Chichester, England.

Bauer, E. 1991. Los montes de España en la Historia. Fundación Conde del Valle de Salazar y Ministry of Agriculture, Madrid, Spain.

Dai, A., and I. F. Fung. 1993. Can climate variability contribute to the 'missing' $\mathrm{CO}_{2}$ sink? Global Biogeochemical Cycles 7:599-609.

DGM (Dirección General de Montes). 1960-1969. Memorias de la Dirección General de Montes, from year 1960 to 1969. Ministry of Agriculture, Madrid, Spain.

DGM (Dirección General de Montes)-Estadística Forestal de España. 1960-1963. Estadística Forestal de España, from year 1960 to 1963. Ministry of Agriculture, Madrid, Spain.

Dixon, R. K., S. Brown, R. A. Houghton, A. M. Solomon, M. C. Trexler, and J. Wisniewski. 1994. Carbon pools and flux of global forest ecosystems. Science 263:185-190.

Font Tullot, I. 1983. Climatología de España y Portugal. Instituto Nacional de Meteorología, Madrid, Spain.

Gandullo, J. M. 1985. Ecología vegetal. Fundación Conde del Valle de Salazar y Escuela Técnica Superior de Ingenieros de Montes, Madrid, Spain.

Grace, J., et al. 1995. Carbon dioxide uptake by an undisturbed tropical rain forest in southwestern Amazonia, 1992 to 1993. Science 270:778-780.

Heath, L. S., and R. A. Birdsey. 1993. Carbon trends of productive temperate forests of the coterminous United States. Water, Air, and Soil Pollution 70:279-293.

ICONA (Instituto para la Conservación de la Naturaleza). 1979. Las coníferas en el primer inventario forestal nacional. Ministry of Agriculture, Madrid, Spain. 
1980. Las frondosas en el primer inventario forestal nacional. Ministry of Agriculture, Madrid, Spain.

1991. Segundo inventario forestal nacional (Galicia, Asturias and Cantabria). Ministry of Agriculture, Madrid, Spain.

1970-1990. Los incendios forestales en España (Forest fires in Spain, from year 1970 to 1990). Ministry of Agriculture, Madrid, Spain.

IFCAV. 1988. (Forest inventory of the Autonomous Basque Community). Consejería de Agricultura de la CAV, Vitoria, Spain.

IPCC (Intergovernmental Panel on Climate Change). 1990 Climate change: the IPCC scientific assessment. J. T. Houghton, G. J. Jenkins, and J. J. Ephraums, editors. Cambridge University Press, Cambridge, UK.

. 1994. Special Report for the UN Framework Convention on Climate Change on Radiative Forcing of Climate Change. Intergovernmental Panel on Climate Change.

Johnson, W. C., and D. M. Sharpe. 1983. The ratio of total to merchantable forest biomass and application to the global carbon budget. Canadian Journal of Forest Research 13 : 372-383.

Kauppi, P. E., K. Mielikäinen, and K. Kuusela. 1992. Biomass and carbon budget of european forests, 1971 to 1990 . Science 256:70-74.

Kauppi, P. E., and E. Tomppo. 1993. Impact of forests on net national emissions of carbon dioxide in West Europe. Water, Air, and Soil Pollution 70:187-196.

Kern, J. S. 1994. Accelerated erosion and the global soil carbon pool. Page 265 in Proceedings of the Fifteenth World Congress of Soil Science, Symposium ID-17, Volume 9 (Supplement). International Society of Soil Science and the Sociedad Mexicana de la Ciencia del Suelo, Mexico City, Mexico.

Kolchugina, T. P., and T. S. Vinson. 1993. Comparison of two methods to assess the carbon budget of forest biomes in the former Soviet Union. Water, Air, and Soil Pollution 70:207-221.

Kurz, W. A., and M. J. Apps. 1993. Contribution of northern forests to the global carbon cycle: Canada as a case study. Water, Air, and Soil Pollution 70:163-176.

Kurz, W. A., and M. J. Apps. 1994. The carbon budget of Canadian forests: a sensitivity analysis of changes in disturbance regimes, growth rates and decomposition rates. Environmental Pollution 83:55-61.

Loetsch, F., F. Zöhrer, and K. E. Haller. 1973. Forest inventory. Volume 2. BLV Verlagsgesellschaft, Munich, Germany.

López Arias, M. 1991. Ciclo biológico de los elementos biogénicos en una plantación de Eucalyptus globulus del SO. de España. Investigaciones Agrarias (Sistemas y Recursos Forestales) 0:75-91.

MAPA (Ministerio de Agricultura, Pesca y Alimentación). 1973-1990. Anuario de Estadística Agraria (Agrarian Statistical Yearbooks, from 1973 to 1990). Ministry of Agriculture, Madrid, Spain.
Miller, A. A. 1966. Climatología. Third edition. Editorial Omega, Madrid, Spain.

Montero, G., J. A. Gómez, and C. Ortega. 1991. Estimación de la productividad aérea en una repoblación de $P$. pinaster Ait. en el centro de España. Investigaciones Agrarias (Sistemas y Recursos Forestales) 0:191-202.

Nabuurs, G. J., and G. M. J. Mohren. 1995. Carbon relations of Dutch forests. In S. Zwerver, R. S. A. R. van Rompaey, M. T. J. Kok, M. M. Berk, editors. Climate change research: evaluation and policy implications. Elsevier Science, Amsterdam, The Netherlands.

Peet, R. K. 1981. Changes in biomass and production during secondary forest succession. Pages 324-338 in D. C. West, H. H. Shugart, and D. B. Botkin, editors. Forest succession: concept and application. Springer-Verlag, New York, New York, USA.

Peinado Lorca, M., and S. Rivas-Martínez, editors. 1987. La vegetación en España. Universidad de Alcalá, Madrid, Spain.

Post, W. M., W. R. Emanuel, P. J. Zinke, and A. G. Stangenberger. 1982. Soil carbon pools and world life zones. Nature 298:155-159.

Prieto, F. 1995. Los incendios forestales. Departamento de Ecología y Medio Ambiente de la Confederación Sindical de Comisiones Obreras, Madrid, Spain.

Reichle, D. E., editor. 1981. Dynamic properties of forest ecosystems. International Biological Program 23. Cambridge University Press, Cambridge, UK.

Rodríguez Murillo, J. C. 1994. The carbon budget of the Spanish forests. Biogeochemistry 25:197-217.

Schlesinger, W. M. 1977. Carbon balance in terrestrial detritus. Annual Review of Ecology and Systematics 8:5181.

Siccama, T. G., S. P. Hamburg, M. A. Arthur, R. D. Yanai, F. H. Bormann, and G. E. Likens. 1994. Corrections to allometric equations and plant tissue chemistry for Hubbard Brook experimental forest. Ecology 75:246-248.

Spiecker, H. 1995. Growth dynamics in a changing environment-long term observations. Plant and Soil 168-169: $555-561$.

Turner, D. P., et al. 1995. A carbon budget for forests of the conterminous United States. Ecological Applications 5: 421-436.

Walter, H., and H. Lieth. 1967. Klimadiagramm-Weltatlas. VEB Gustav Fischer Verlag, Jena, Germany.

Waring, R. H., and W. H. Schlesinger. 1985. Forest ecosystems: concepts and management. Academic Press, Orlando, Florida, USA.

Whittaker, R. H., and P. L. Marks. 1975. Methods of assessing terrestrial productivity. Pages 55-118 in H. Lieth and R. H. Whittaker, editors. Primary productivity of the Biosphere, Springer-Verlag, New York, New York, USA.

Wisniewski, J., and R. Neil Sampson, editors. 1993. International Workshop on Terrestrial biospheric carbon fluxes: quantification of sinks and sources of $\mathrm{CO}_{2}$, Bad Harzburg, Germany, March 1993. Water, Air, and Soil Pollution 70(14). 